\title{
KREATIVITAS DAN PEMBELAJARAN CS MARCHINGBLEK UNIVERSITAS KRISTEN SATYA WACANA
}

\author{
Benidiktus Candra Pamungkas ${ }^{1}$, Rosvania Jouzanda Kathlya ${ }^{2}$ \\ Pendidikan Seni, Universitas Negeri Semarang ${ }^{1}$ \\ benidiktusc@gmail.com ${ }^{l}$ \\ Manajemen, Universitas Kristen Satya Wacana ${ }^{2}$ \\ jouzanda@gmail.com ${ }^{2}$
}

\begin{abstract}
Abstrak
CS Marchingblek merupakan kelompok marchingband dari Universitas Kristen Satya Wacana Salatiga dan memiliki keunikan dalam penggunaan instrumen musiknya. Tujuan penelitian ini adalah untuk memahami proses kreativitas dan pembelajaran CS Marchingblek yang dianalisis menggunakan teori kreativitas Rhodes dengan metode penelitiannya kualitatif deskriptif. Hasil penelitian menunjukkan bahwa kreativitas penciptaan CS Marchingblek dikarenakan adanya relasi antar individu (person) yaitu Girindra, Yakub, dan Kimpul yang memiliki pengetahuan dan pengalaman musik untuk menyelesaikan permasalahan kurang meriahnya pawai budaya dan mengangkat isu tentang global warming (process). Hal itu merupakan bagian dari motivasi terciptanya kreativitas (press) yaitu masalah sampah dan kesan terhadap pawai OMB yang kurang meriah. Sehingga penyelesaian masalah tersebut menghasilkan sebuah objek (product) yaitu berupa CS Marchingblek. Sedangkan proses pembelajaran CS Marchingblek menggunakan metode praktik dan audio visual dengan memanfaatkan platform YouTube. Dalam pembelajaran praktik, instruktur memberikan contoh tentang cara memainkan masing-masing alat musik dan pola-pola permainannya untuk dapat ditiru oleh mahasiswa baru. Selain melalui tatap muka, dilakukan juga pemberian video tutorial yang diunggah melalui platform YouTube untuk memudahkan mahasiswa baru dapat mengakses dimana dan kapan saja. CS Marchingblek tidak hanya mengajarkan tentang bermain musik, namun juga pendidikan karakter seperti kedisiplinan, kepedulian manusia dan lingkungan, serta kesederhanaan hidup yang bermanfaat.
\end{abstract}

Kata kunci: kreativitas; marchingblek; pembelajaran musik; pendidikan karakter

\begin{abstract}
CS Marchingblek is a marching band group from the Satya Wacana Christian University Salatiga and is unique in its use of musical instruments. The purpose of this study is to understand the process of CS Marchingblek's creativity and learning which were analyzed using Rhodes's creativity theory with descriptive qualitative research methods. The results showed that the creativity of CS Marchingblek's creation was due to relations between individuals (person) Girindra, Jacob, and Kimpul who had the knowledge and experience of music to solve the problem of the lackluster cultural march and raised issues about global warming (process). This is part of the motivation to create creativity (press), which is the problem of garbage and the impression of a less lively OMB. So solving the problem produces an object (product) in the form of CS Marchingblek. While the CS Marchingblek learning process uses practical methods and audiovisual by utilizing the YouTube platform. In practical learning, the instructor gives examples of how to play each musical instrument and its playing patterns for new students to emulate. In addition to face-to-face meetings, tutorial videos are also uploaded on the YouTube platform to make it easier for new students to access anywhere and anytime. CS Marchingblek not only teaches about playing music but also character education such as discipline, human care and the environment, as well as the simplicity of life that is beneficial.
\end{abstract}

Keywords: creativity; marchingblek; music learning; value education 


\section{Pendahuluan}

Kreativitas menjadi aspek yang penting dalam kehidupan karena kreativitas merupakan suatu kemampuan yang berarti dalam proses kehidupan (Kusumah, 2009). Menurut Effendi (2016) kreativitas adalah kemampuan untuk membuat kombinasi baru berdasarkan data, informasi, atau unsur-unsur yang ada. Dengan kata lain, kreativitas dapat menciptakan sesuatu yang baru, baik sesuatu yang benar-benar merupakan hal baru atau penggabungan suatu ide baru yang diperoleh dengan cara menghubungkan beberapa hal yang sudah ada dan menjadikannya suatu hal baru.

Kreativitas merupakan kata yang sering terdengar dan muncul di hampir semua aspek kehidupan manusia. Kreativitas digunakan manusia dalam mempertahankan eksistensinya sebagai individu dan dalam masyarakat. Dalam kehidupan manusia pasti ditemukan masalah-masalah yang muncul setiap saat, dan bagaimana manusia tersebut menyelesaikan masalahnya dengan sebuah cara yang dianggap benar merupakan hasil dari pola pikir kreatif manusia tersebut. Hal tersebut sejalan dengan pemikiran Solso et al. (2007) tentang kreativitas yang merupakan aktivitas kognitif yang menghasilkan cara pandang baru terhadap suatu masalah atau situasi. Cara pandang baru tersebut dapat membantu menyelesaikan masalah yang sebelumnya tidak menemukan titik terang untuk penyelesaiannya. Menurut Tolah (2014) kreativitas dapat diartikan sebagai kemampuan untuk menghasilkan atau mewujudkan sesuatu yang berbeda dari yang lain. Menurut Kristiawan (2016) kreativitas adalah proses inovatif untuk mewujudkan suatu ide menjadi nyata. Pengertian kreativitas pada umumnya adalah gagasan untuk menciptakan sesuatu baik berupa benda mati maupun ide dan tentunya dengan menjunjung tinggi nilai keaslian, daya imajinatif, dan ekspresif.

Kreativitas sebenarnya tidak hanya muncul dari individu, melainkan juga dapat muncul dari lingkungan karena adanya determinant yang memengaruhi manusia untuk berpikir kreatif. Rhodes merumuskan kreativitas dalam "Four P's of Creativity: Person, Process, Product, and Press" (Munandar dalam Utami, 2014), faktor pemicu kreativitas adalah person (individu) yang memiliki keunikan yang melekat dalam dirinya yaitu rasa ingin tahu, daya imajinasi, dan kemampuan berpikir dan menalar. Process (proses) yang mendasari terbentuknya kreativitas bermula dari tahapan dalam berkegiatan yang membebaskan individu untuk bereksperimen dalam menjalankannya. Proses tersebut didukung dengan pengetahuan (knowledge) dari individu yang memungkinkan untuk bereksperimen. 
Product (produk) berdasarkan pengalaman individu tersebut dalam menjalankan kegiatannya, muncullah kemampuan individu untuk mencipta dan menghasilkan produkproduk kreatif. Produk yang dimaksud merupakan perwujudan dari buah pikir kreatif yang menjadi suatu objek material. Produk yang dihasilkan tidak hanya berupa kesenian, melainkan dapat berupa tulisan, artikel, dan metode yang telah dibukukan. Faktor terakhir adalah press (pendorong) atau dapat juga disebut motivasi, merupakan suatu kondisi yang dialami individu untuk berperilaku kreatif. Motivasi tersebut dapat berasal dari dalam individu (intrinsik) tersebut ataupun dari luar (ekstrinsik). Motivasi instrinsik merupakan kemauan yang tumbuh dari kesadaran diri untuk membangun pengalaman dan pengetahuan (Utami, 2014). Motivasi ekstrinsik merupakan suatu penghargaan dan adanya unsur kebutuhan untuk mencapai kepuasan dari masyarakat sekitar.

Salah satu perwujudan kreativitas muncul dalam kelompok CS Marchingblek Universitas Kristen Satya Wacana (UKSW) Salatiga. Berdiri pada tahun 2011 yang mengusung konsep musik marchingband - musik untuk baris berbaris. Bentuk kreativitas marchingblek terletak pada instrumen yang digunakan, dengan lebih memilih barangbarang bekas sebagai pengganti instrumen marchingband yang sesungguhnya. Ide tersebut muncul dari Founder marchingblek atas keprihatinannya terhadap global warming yang sudah terjadi di seluruh bagian bumi karena banyaknya polusi dan sampah yang melimpah.

CS Marchingblek hadir pertama kali dalam rangka memeriahkan Pawai Budaya UKSW dalam masa Orientasi Mahasiswa Baru (OMB) pada tahun 2011, setelah mengamati Pawai Budaya 2010 yang hanya menyajikan pagelaran kostum terkait dengan nuansa dan juga busana daerah masing-masing provinsi di Indonesia. Pawai kala itu cukup sepi dikarenakan kurangnya unsur musik yang muncul. CS Marchingblek mengajarkan mahasiswa baru yang terpilih untuk bersama-sama memukul instrumen musiknya masingmasing. Tidak ada kata malu menggunakan barang bekas, namun rasa bangga yang didapat sebab mereka dapat mengolah barang bekas tersebut menjadi barang yang bermanfaat.

Pengajaran instrumen perkusi tersebut tidak hanya berpusat pada bagaimana teknik-teknik memukul dan membunyikan instrumen, tetapi juga didampingi penularan nilai pendidikan karakter yang diyakini sebagai motto dalam ber-marchingblek. Motto yang pertama adalah malu jika terlambat, kedua nyampah itu biadab, dan ketiga hidup murah dan bermanfaat. Pendidikan karakter yang tertuang dalam ketiga motto tersebut adalah pendidikan karakter yang disiplin, peduli dan kreatif. Hidup murah dan bermanfaat maksudnya adalah kita harus dapat memanfaatkan apa saja yang dimiliki dan ada 
disekitarnya untuk menghasilkan sesuatu. Hal ini menuntut seseorang untuk kreatif, begitu juga dengan CS Marchingblek.

Penjelasan yang sudah diberikan menjadi latar belakang penulis untuk menganalisis kreativitas dan pembelajaran musik CS Marchingblek. Peneliti menggunakan teori kreativitas dari Rhodes guna menganalisis proses kreatif dalam CS marchingblek. Rhodes merumuskan kreativitas dalam “Four P's of Creativity: Person, Process, Product, and Press.

\section{Metode Penelitian}

Pendekatan yang dipakai penulis dalam penelitian ini adalah kualitatif. Kualitatif merupakan penelitian yang bersifat naratif, berupa pemaparan hasil wawancara dan observasi. Menurut Bogdan dan Taylor (dalam Moleong, 2002) bahwa penelitian kualitatif adalah prosedur penelitian yang menghasilkan data deskriptif berupa kata-kata tertulis atau lisan dari orang-orang dan perilaku yang diamati. Kirk dan Miller (dalam Sumaryanto, 2007) mengartikan penelitian kualitatif sebagai tradisi tertentu dalam penelitian sosial yang secara fundamental bergantung pada pengamatan terhadap manusia dalam kawasannya sendiri dan berhubungan dengan orang-orang tersebut dalam bahasa dan peristilahannya.

Penelitian ini dilakukan dengan teknik pengumpulan data berupa wawancara dan observasi. Wawancara dilakukan kepada dua orang ketua CS Marchingblek dari tahun 2013-2019 yaitu Adya Nadira Arzak (ketua 2013-2016) dan Ardo Brian Ramadhan (20162019). Hal tersebut didasari pada awal mula pemanfaatan platform YouTube sebagai media pembelajaran CS Marchingblek. Sedangkan observasi dilakukan sejak tahun 2011.

Data yang terkumpul dari proses wawancara dan observasi dianalisis menggunakan teori dari Rhodes tentang aspek-aspek dalam kreativitas yang dirumuskan ke dalam "Four P's of Creativity: Person, Process, Product, and Press". Penulis akan memaparkan proses terbentuknya CS Marchingblek yang dimulai dari person atau tokoh dibalik berdirinya CS Marchingblek, kemudian process (proses) terbentuknya CS Marchingblek, product berupa bentuk, struktur musik, dan pembelajaran dalam CS Marchingblek. Press adalah alasan atau masalah yang muncul sehingga terbentuk CS Marchingblek. 


\section{CS Marchingblek}

CS Marchingblek Universitas Kristen Satya Wacana (UKSW) Salatiga merupakan salah satu contoh hasil kreativitas dalam bidang musik yang terbentuk pada tanggal 12 Agustus 2011. CS Marchingblek merupakan buah pikir dari 3 orang punggawanya yaitu Yakub, Kimpul, dan Girindra yang berawal dari keresahannya terhadap pawai budaya 2010 yang kurang semarak. Mereka bertiga saat itu masih berstatus mahasiswa UKSW dan juga musisi band Kota Salatiga. Menurut Yakub, Kimpul dan Girindra, minimnya bunyibunyian terutama musik dianggap kurang memeriahkan pawai kala itu. Dibantu oleh Yakub, Kimpul, dan Girindra serta beberapa teman dari berbagai jurusan dan praktisi marchingband bernama Christian Chandra (Mahasiswa Jurusan Seni Musik) kemudian mengajukan pembentukan CS Marchingblek kepada Pembantu Rektor 3 dan terbentuklah CS Marchingblek.

Kata CS sendiri memiliki arti calon sarjana, hal ini sebagai sebuah harapan dan motivasi para anggota CS Marchingblek untuk menyelesaikan studinya dan mendapatkan gelar sarjana. Machingblek berasal dari kata marchingband-kelompok musik yang identik dengan baris-berbaris. Marchingblek merupakan adaptasi dari drumblek, namun mempunyai jumlah anggota instrumen yang lebih banyak. Kesenian drumblek merupakan seni musik dalam bentuk perkusi yang alat musiknya berasal dari barang-barang bekas seperti drum dan blek (Susanto, 2017). Drum adalah tong plastik besar, sedangkan blek merupakan adopsi dari kata blikje dalam bahasa Belanda yang berarti kaleng, tetapi orang Jawa lebih fasih mengucapkan dengan kata blek (Supangat, 2014). Namun marchingblek memiliki anggota pemain lebih banyak dibanding dengan drumblek.

CS Marchingblek memiliki organisasi yang terdiri dari penanggung jawab yaitu Pembantu Rektor 3, ketua, bendahara, sekretaris, dewan kehormatan, sarana pra-sarana atau perlengkapan, keamanan, mayoret, gitapati, dan instruktur yang dibagi sesuai divisinya. Dewan Kehormatan menjadi hal yang menarik dalam struktur organisasi CS Marchingblek. Dewan Kehormatan terbentuk mulai tahun 2012 beranggotakan pengurus dan juga instruktur-instruktur yang telah mendapatkan gelar sarjana. Tugasnya adalah memberi masukan dan saran tentang bagaimana mengurus dan mengajarkan Marchingblek serta memberi solusi terhadap masalah-masalah yang terjadi. Dewan Kehormatan hadir sebagai bagian dari penyemangat dan penyemarak dari proses latihan hingga pertunjukan dalam Pawai Budaya UKSW. 
Mayoret bertugas sebagai pusat komando utama untuk menentukan tempo dan lagu yang dimainkan serta cepat lambatnya barisan berjalan. Gitapati bertugas sebagai pengatur barisan dan membantu menjaga tempo serta mengingatkan pattern atau bagian-bagian lagu yang sedang dimainkan. Mahasiswa baru disebut sebagai pasukan Marchingblek yang memainkan instrumen blek untuk menggelegarkan Kota Salatiga. Mahasiswa sebagai peserta Marchingblek menjalani masa pelatihan selama dua minggu. Dalam masa pelatihan tersebut, mereka belajar cara memainkan masing-masing instrumen dan memadukan berbagai macam instrumen tersebut sehingga terdengar baik dan harmonis. Peserta CS Marchingblek pada tahun 2011 tercatat berjumlah 500 orang mahasiswa baru.

\section{Kreativitas dalam CS Marchingblek}

Merujuk teori kreativitas dari Rhodes tentang 4P digunakan untuk menganalisis kreativitas CS Marchingblek. Person dalam CS Marchingblek adalah Yakub, Kimpul, dan Girindra. Person adalah seseorang atau kelompok yang memiliki ide untuk membentuk CS Marchingblek. Permasalahan atau press yang memicu person untuk membentuk CS Marchingblek adalah kurang meriahnya pawai OMB UKSW dan keprihatinan terhadap isu global warming yang terjadi. CS Marchingblek dibentuk untuk dapat lebih memeriahkan kegiatan pawai OMB UKSW dengan memanfaatkan barang-barang bekas untuk membantu mengurangi global warming.

Process dalam kreativitas CS Marchingblek didasari oleh Yakub, Kimpul, dan Girindra yang memiliki pengetahuan (knowledge) musik. Kemudian mereka dibantu oleh Christian seorang praktisi marchingband, maka dari hasil diskusinya memutuskan untuk membentuk marchingband dengan menggunakan barang bekas. Mereka menentukan tong, gerigen, dan kentongan sebagai pengganti instrumen yang umumnya digunakan dalam marchingband. Proses ini dilakukan untuk menyelesaikan permasalahan (press) yang ada. Sinergi antara person, press, dan process tersebut menghasilkan product yaitu CS Marchingblek.

Pada tahun 2011, CS Marchingblek menggunakan beberapa instrumen saja, di antaranya bass dari tong plastik besar, tenor dari jirigen plastik yang umumnya untuk menampung minyak, snare dari tong seng atau besi, kentongan dari bambu, trio tom, glockenspiel, dan cakram bekas motor juga peluit sebagai pengatur tempo. Mallet yang digunakan berasal dari bambu dan dililit menggunakan karet ban bekas kecuali untuk snare. Trio tom dan glockenspiel merupakan dua buah instrumen yang tidak berasal dari 
barang bekas. Trio tom berfungsi sebagai penjaga tempo dan pengisi fill in. Glockenspiel berperan sebagai melodi-yang merupakan instrumen perkusi bernada menggunakan tangga nada diatonis. Kemudian, pada tahun 2013 mulailah terjadi penambahan instrumen tiup (trumpet, trombone, dan saxophone) yang diharapkan semakin memeriahkan nuansa CS Marchingblek. Instrumen-instrumen tiup berperan sebagai harmonisasi dari melodi yang dihasilkan oleh glockenspiel.

CS Marchingblek memainkan lagu-lagu etnis di Indonesia seperti Jaranan, Manuk Dadali, Yamko Rambe Yamko, dan Gundul-Gundul Pacul. Mereka juga memainkan lagu pop seperti Rumah Kita dan Kolam Susu serta tidak ketinggalan yaitu Mars Satya Wacana dan Mars Marchingblek. CS Marchingblek juga memainkan lagu-lagu etnis yang sejalan dengan sebutan UKSW yaitu Indonesia mini-suku Indonesia dari mana saja dapat dijumpai di UKSW. Pameran kostum berunsur etnis dari seluruh daerah di Indonesia turut memeriahkan pawai budaya UKSW tersebut. Kostum-kostum tersebut merupakan bentuk solidaritas dan pengenalan suku-suku yang di Indonesia kepada masyarakat Salatiga. Penampilan pawai CS Marchingblek dapat dilihat pada gambar 1 dan 2.

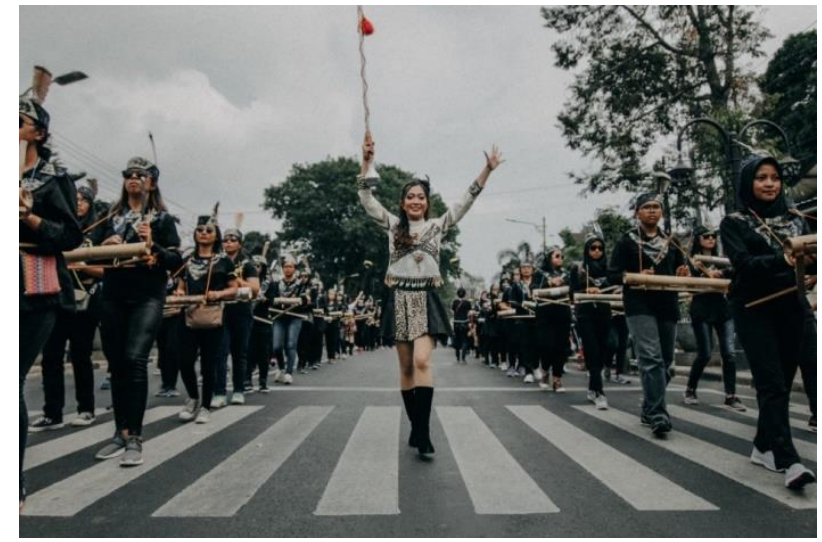

Gambar 1. Pawai CS Marchingblek

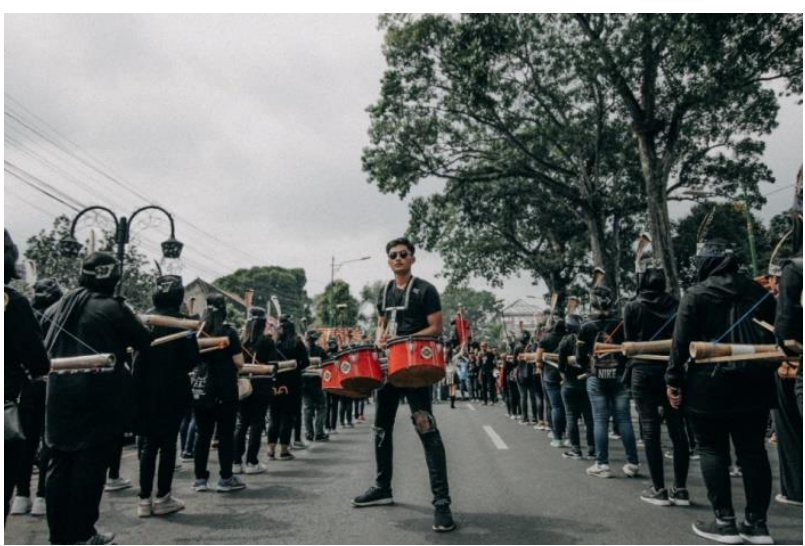

Gambar 2. Pawai CS Marchingblek 


\section{Pembelajaran CS Marchingblek}

Metode pembelajaran CS Marchingblek menggunakan pembelajaran praktik dan audio visual dengan memanfaatkan platform YouTube. Pembelajaran praktik dimulai dari demonstrasi oleh instruktur secara keseluruhan CS Marchingblek dalam pembukaan OMB, yang bertujuan untuk menarik minat para peserta CS Marchingblek. Setelah memasuki masa latihan, instruktur mendemonstrasikan teknik bermain alat-alat musiknya secara berkelompok sesuai dengan pembagian divisi yang sebelumnya telah dilakukan. Hal ini dianggap cukup mudah dalam penyampaian karena para peserta CS Marchingblek hanya dituntut untuk menirukan demonstrasi yang telah dijelaskan oleh instruktur. Namun karena peserta CS Marchingblek memiliki minat, fokus, dan pengalaman musik yang berbedabeda, sehingga kesulitan dalam menirukan juga dapat terjadi. Solusi untuk hal ini adalah mengajarkan secara terpisah peserta CS Marchingblek yang dianggap belum mampu mengikuti.

Instruktur dengan sabar mendampingi para peserta CS Marchingblek tersebut, memberi apresiasi dan motivasi hingga para peserta CS Marchingblek dapat memainkan sesuai dengan arahan. CS Marchingblek memiliki prinsip tidak ada para peserta CS Marchingblek yang tidak dapat memainkan alat musik dari barang bekas, oleh karena itu instruktur selalu bekerja keras dalam pembelajaran ber-CS Marchingblek.

Metode audio visual berupa video tutorial diunggah ke dalam YouTube. Video tutorial tersebut berguna sebagai panduan para peserta CS Marchingblek (mahasiswa baru) dalam melakukan latihan mandiri. YouTube digunakan oleh karena akses yang mudah, murah, dan dapat diakses dimanapun. Peserta CS Machingblek diberi tanggung jawab untuk merawat alatnya dengan baik dari kegiatan latihan hingga dengan pawai budaya selesai, oleh karena itu peserta CS Machingblek membawa pulang alat musiknya dan dapat berlatih dimanapun tanpa selalu mengandalkan pengajaran dari para instruktur. Terbukti dengan video tutorial dapat membantu peserta untuk menghafal dan memainkan pattern dan bagian-bagian dari setiap lagu yang dimainkan dalam pawai OMB UKSW.

Kreativitas dalam pembelajaran yang ditularkan oleh instruktur kepada peserta CS Marchingblek terkait pada penggunaan barang-barang bekas yang sebenarnya sudah tidak terpakai tetapi mereka bersihkan dan cat ulang sehingga dapat digunakan untuk bermusik. Hal ini juga didasari pada isu global warming karena banyaknya sampah-sampah yang sulit terurai dan tidak dimanfaatkan dengan baik. Juga perilaku membuang sampah 
sembarangan yang banyak terjadi sehingga mencemari lingkungan sekitar, khususnya sungai.

Penjabaran tersebut terhadap daya kreativitas yang diciptakan oleh para pengurus dan instruktur, untuk motivasi kreativitas dari pasukan CS Marchingblek adalah kebebasan untuk menghias instrumen yang telah diberikan. Hal ini dilakukan untuk mengajarkan tanggung jawab yang diberikan kepada mereka, alat yang sudah diterima sewajarnya harus dijaga, dirawat, dan diperindah sesuai kreasinya masing-masing.

Pembelajaran CS Marchingblek tidak hanya berpusat pada kompetensi bermain musik tetapi ada pula pendidikan nilai-nilai dari tiga moto CS Marchingblek yaitu 1) malu jika terlambat, 2) nyampah itu biadab, dan 3) hidup murah dan bermanfaat. Malu jika terlambat terkait pada pemberian tanggung jawab yang sudah dibebankan kepada pengurus, instruktur - termasuk mayoret dan gitapati—serta khususnya mahasiswa baru. Selain tanggung jawab terhadap instrumennya yang dibawa pulang setelah selesai latihan - kecuali Bass dan Glockenspiel — mereka juga bertanggung jawab pada komitmen untuk ber-CS Marchingblek. Maksudnya adalah kedisplinan sangat penting dalam CS Marchingblek, sebagai contoh jika salah satu divisi ada yang telambat maka penampilan CS Marchingblek tidak akan berjalan baik karena harus menunggu divisi tersebut datang. Nyampah itu biadab terkait dengan isu global warming dan cinta terhadap lingkungan, yang kemudian dihubungkan dengan moto yang ketiga yaitu hidup murah dan bermanfaat sebagai bentuk kesederhanaan mengolah barang-barang disekitarnya-tentu dengan biaya murah — untuk memberi dampak atau manfaat bagi orang disekitar.

Menurut Plato (dalam Djohan 2009) dalam pendidikan, musik memiliki kedudukan tertinggi karena tidak ada disiplin yang dapat ke dalam jiwa dan menyertai dengan kemampuan berjenjang melebihi irama dan melodi. Pendidikan musik menurut Plato tidak hanya membentuk kemampuan bermusik saja tetapi dengan menyentuh jiwa peserta didik, aspek apapun dalam peserta didik tersebut dapat dibentuk khususnya emosional dan spiritual. Sedangkan menurut Triyanto (2017) pendidikan merupakan pembentukan peserta didik yang humanis. Humanis berarti menyelaraskan antara daya intelektual, emosional dan spiritual. Sejalan dengan Triyanto, menurut Freire pendidikan bertujuan untuk memanusiakan manusia. Maka dari itu CS Marchingblek membentuk para anggotanya tidak hanya unggul dalam hal bermusik tetapi juga memiliki rasa tanggung jawab, disiplin serta kepedulian terhadap orang lain dan lingkungan disekitarnya. 
Dalam proses pembelajaran CS Marchingblek, pendidikan karakter tersebut telah tercapai. Pemahaman moto telah ditanamkan kepada para instruktur dan dilaksanakan dengan baik. Pemahaman dan pelaksanaan yang baik dari instruktur tersebut adalah contoh yang dapat diikuti oleh para mahasiswa baru. Namun tidak semua mahasiswa baru dapat memahami dan melaksanakannya dengan baik, sebagai contoh masih ada mahasiswa baru yang datang terlambat maupun lupa membawa perlengkapan untuk latihan.

\section{Kesimpulan}

CS Marchingblek merupakan sebuah solusi kreatif atas permasalahan sampah dan sebagai pemeriah pawai budaya UKSW. CS Marchingblek tidak hanya memanfaatkan sampah-barang bekas_-menjadi instrumen musik, tetapi juga mengajarkan anggotanya untuk menjaga lingkungan dengan tidak membuang sampah sembarangan. Kreativitas dalam penciptaan CS Marchingblek muncul karena adanya relasi antar individu (person) yaitu Girindra, Yakub, dan Kimpul yang berpengetahuan dan memiliki pengalaman bermusik untuk memahami dan menyelesaikan permasalahan tentang kurang meriahnya pawai budaya dan mengangkat isu tentang global warming (process). Kesenjangan tersebut merupakan bagian dari motivasi terciptanya kreativitas (press) yaitu masalah sampah dan pandangan terhadap OMB yang kurang meriah. Kemudian penyelesaian masalah tersebut menghasilkan sebuah objek (product) yaitu berupa CS Marchingblek. Penciptaannyapun tidak menghabiskan biaya yang besar, melainkan hanya memanfaatkan potensi diri dan didukung dengan sumber daya yang tersedia secara murah bahkan gratis dari lingkungan.

Pembelajaran CS Marchingblek menggunakan metode praktik dan audio visual dengan memanfaatkan platform YouTube. Pembelajaran praktik terbagi menjadi beberapa divisi yaitu bass, snare tom, dan glockenspiel. Dalam pembelajaran praktik, instruktur memberi contoh cara bermain masing-masing alat musiknya dan pola-pola permainannya. Mahasiswa baru tidak diwajibkan untuk dapat membaca notasi musik, namun hanya mengimitasi pola-pola yang telah diajarkan oleh instruktur guna memudahkan pemberian materi. Platform YouTube digunakan untuk menggunggah video tutorial, sehingga mahasiswa baru dapat mengaksesnya dimana saja dan kapan saja. 


\section{Kepustakaan}

Djohan, D. (2009). Psikologi Musik. Best Publisher.

Effendi, M. (2016). Integrasi Pembelajaran Active Learning dan Internet-Based Learning dalam Meningkatkan Keaktifan dan Kreativitas Belajar. Nadwa, 7(2), 283. https://doi.org/10.21580/nw.2013.7.2.563

Kristiawan, Y. (2016). Pengembangan Kreativitas Musik Dalam Pembelajaran Seni Budaya (Musik) Di SMA Negeri 1 Pati. Jurnal Seni Musik.

Kusumah, W. (2009). Mengapa Kreativitas Itu Penting? Halaman 1 - Kompasiana.com. Kompasiana. https://www.kompasiana.com/wijayalabs/54fece18a33311f65a50f833/mengapakreativitas-itu-penting

Moleong, L. J. (2002). Metodologi Penelitian Kualitatif (R. R. Karya (ed.)).

Solso, L. R., Maclin, O. H., \& Maclin, M. K. (2007). Psikologi Kognitif (M. Rahardanto \& K. Batuadji (eds.)). Erlangga.

Sumaryanto, T. F. (2007). Pendekatan Kuantitatif Dan Kualitatif Dalam Penelitian Pendidikan Seni. UNNES Press.

Supangat, E. (2014). Drumblek Seni Budaya Asli Salatiga. Kantor Perpustakaan Arsip Daerah Kota Salatiga.

Susanto, F. (2017). Strategi Pengelolaan Kelompok MusikPerkusi Drumblek Gempar di Salatiga. Jurnal Tata Kelola Seni, 2(1), 74-90. https://doi.org/10.24821/jtks.v2i1.1816

Tolah, A. F. (2014). Proses Berkarya Grup Musik Distorsi Akustik. Catharsis: Journal of Arts Education, 3(2).

Triyanto. (2017). Spirit Ideologis Pendidikan Seni (C. P. Nusantara (ed.)).

Utami, S. U. P. (2014). Peningkatan Kreativitas Seni Melalui Bermain Membentuk Bebas Terarah Pada Anak Kelompok B Di TK Pedagogia Yogyakarta. Universitas Negeri Yogyakarta.

\section{Narasumber Wawancara}

Adya Nadira Arzak, 26. Ketua CS Marchingblek 2013-2016. Salatiga, 16 Oktober 2018.

Ardo Brian Ramadan, 23. Ketua CS Marchingblek yang masih menjabat. Salatiga, 16 Oktober 2018. 